\title{
INTERLEUKIN 4 DRIVES \\ PHYTOHEMAGGLUTININ-ACTIVATED T CELLS THROUGH SEVERAL CELL CYCLES: NO SYNERGISM BETWEEN INTERLEUKIN 2 AND INTERLEUKIN 4
}

\author{
Thomas Lehrnbecher, ${ }^{1} \quad$ Hartmut Merz,' Walter Sebald, ${ }^{1}$ Martin Poot $^{2}$
}

\begin{abstract}
Cell kinetic studies of $\mathrm{T}$ cells stimulated with the interleukin 2 (Il-2), Il-4, or both lymphokines were performed with conventional $\left[{ }^{3} \mathrm{H}\right]$ thymidine incorporation and with the bivariate $\mathrm{BrdU} / \mathrm{Hoechst}$ technique. $\mathrm{II}-2$ and $\mathrm{Il}-4$ are able to drive phytohemagglutininactivated $\mathbf{T}$ cells through more than one cell cycle. Neither synergistic nor inhibitory effect on T-cell proliferation was seen for the stimulation with both Il-2 and Il-4 as compared with the effect of Il-2 alone. The quantitative data of the cell cycle distribution of phytohemagglutininactivated $T$ cells suggest that the population of Il-4-responsive cells is at least an overlapping population, if not a real subset of the population of the Il-2-responsive cells.

Copyright $\odot 1991$ by W.B. Saunders Company
\end{abstract}

Interleukin 4 (Il-4) is a T cell and mast-cell-derived polypeptide which was originally described as a B-cell growth factor, ${ }^{1}$ but has recently been shown to have an array of biological effects on a variety of cell types. ${ }^{2}$ In addition, it is becoming evident that Il-4 participates in complex regulatory pathways with other lymphokines. Il-4 seems to inhibit the Il-2-dependent generation of human lymphokine-activated killer cells ${ }^{3,4}$ and Il-2induced proliferation and differentiation of $B$ cells and B-cell lines. ${ }^{5,6}$ On the other hand, the Il-4 enhancement of expression of major histocompatibility complex class II antigen can be inhibited by gamma interferon. ${ }^{7}$ Il-4 has also been shown to promote the proliferation of mitogen-activated human $T$ cells. ${ }^{8,9,10}$ Recent reports investigating the role of $\mathrm{Il}-4$ in Il-2-dependent responses have yielded discordant findings. ${ }^{9,11,12} \mathrm{IJ}-2$ and Il-4 together supported a greater degree of proliferation of a number of human T-cell clones ${ }^{12}$ and mitogenstimulated $\mathrm{T}$ cells ${ }^{9}$ than did either lymphokine alone. In contrast, the addition of Il- 4 to cultures of $\mathrm{T}$ cells stimulated with low concentrations of both anti-CD3

From the Department of Physiological Chemistry ${ }^{1}$ and the Department of Human Genetics, ${ }^{2}$ University of Würzburg, Würzburg, Germany.

Address reprint requests to: T. Lehrnbecher, Kinderklinik und Kinderpoliklinị der Universität Würzburg, Josef-SchneiderStrasse 2, D-8700 Würzburg, Germany.

Copyright $₫ 1991$ by W.B. Saunders Company

$1043-4666 / 91 / 0306-0003 / \$ 5.00 / 0$

KEY WORDS: BrdU-Hoechst/cell cycle/flow cytometry/interleukin 2 /interleukin 4 monoclonal antibodies (mAb) and $\mathrm{Il}-2$ reduced the proliferation response. ${ }^{11}$

Most data about T-cell growth and proliferation stimulated with Il-2 or Il-4 are measurements of the $\left[{ }^{3} \mathrm{H}\right]$ thymidine incorporation in different test systems. ${ }^{8-12}$ There is very little information available concerning cell kinetics of $T$ cells stimulated with Il-2, Il-4, or the combination of Il-2 and Il-4. In this study, we apply a novel method for the examination of T-cell proliferation which is based on incorporation of 5-bromo-2'-deoxyuridine (BrdU) into the DNA of proliferating cells. The quenching of Hoechst 33258 dye (Hoechst) fluorescence allows to separate cells according to the number of cell cycles (CC) the cells traversed during the observation period. The unique attribute of this assay is that it provides a clear distinction between different CC compartments of at least three consecutive CCs. In this study, we investigate the proliferation kinetics of activated $\mathrm{T}$ cells with Il-2, Il-4, or the combination of Il-2 and Il-4 in view of a putative synergism between the lymphokines.

\section{RESULTS}

The proliferative response of phytohemagglutinin (PHA)-activated $\mathrm{T}$ cells was measured by means of $\left[{ }^{3} \mathrm{H}\right]$ thymidine incorporation (Fig. 1). Without the addition of any lymphokine, PHA-activated $\mathrm{T}$ cells show only a weak incorporation of $\left[{ }^{3} \mathrm{H}\right]$ thymidine. Stimulation of the PHA-activated T cells with Il- 2 or with the combination of $\mathrm{Il}-2$ and Il-4 gave similar results. After 24,48 , and $72 \mathrm{~h},\left[{ }^{3} \mathrm{H}\right]$ thymidine uptake 


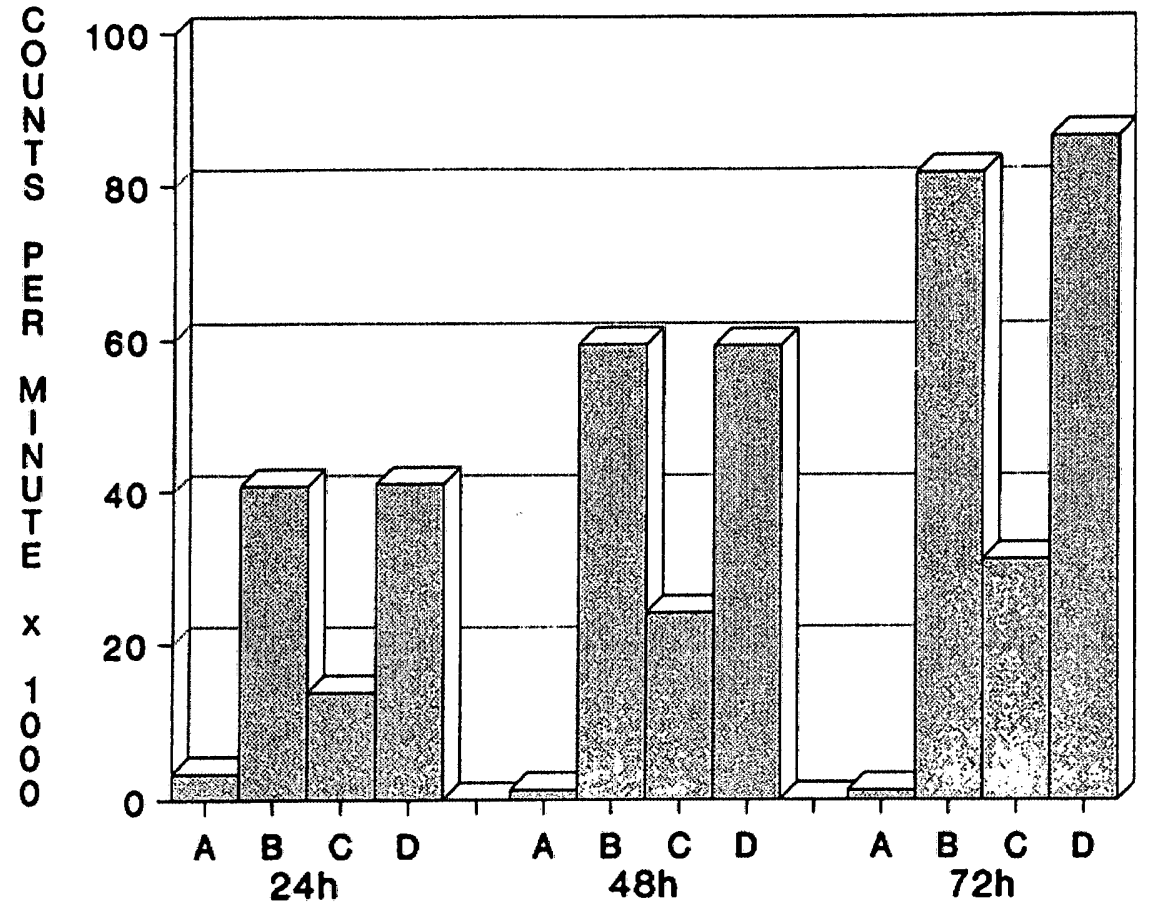

Figure 1. [ $\left.{ }^{3} \mathrm{H}\right]$ Thymidine incorporation in PHA-activated T cells.

T cells are stimulated with (A) no lymphokine, (B) Il-2 (200 $\mathrm{U}),(\mathrm{C}) \mathrm{Il}-4(200 \mathrm{U})$, and (D) Il-2 (200 U) and Il-4 (200 U) for 24,48 , or $72 \mathrm{~h}$. was comparable for both stimulative regimes. Neither a significant additive nor an inhibitory effect was seen for the combination of both lymphokines as compared with Il-2 alone. The $\left[{ }^{3} \mathrm{H}\right]$ thymidine uptake afforded by Il-4 alone was approximately one third of that by II- 2 or the combination of II-2 and II-4 for each observed time period.

These results were confirmed both by the detection of $\left[{ }^{3} \mathrm{H}\right]$ thymidine incorporation by means of in situ autoradiography and by a nonradioactive in situ detection, which allows a monitoring of proliferating cells through incorporation of the thymidine analogue $\mathrm{BrdU}$ and subsequent localization using a specific monoclonal antibody. Both methods gave comparable results (data not shown).

The proliferative response of activated $T$ cells was examined in more detail by using continuous bromodeoxyuridine labeling followed by Hoechst/ethidium bromide flow cytometry. Figure 2 shows representative cytograms of cultures exposed to the type of interleukin indicated for $72 \mathrm{~h}$. The abscissa represents Hoechst fluorescence (blue), which is quenched if $\mathrm{BrdU}$ is incorporated during $\mathrm{S}$ phase traverse of cells, whereas the ordinate shows BrdU-insensitive ethidium bromide fluorescence (red). Each dot represents an individual cell; clusters arise where cells with similar fluorescence intensity concur.

In the untreated control culture, all cells remained in the resting state (labeled as $\mathrm{G} 0 / \mathrm{G} 1$ ). In contrast, the panel showing the cytogram of the Il-2-treated culture shows few cells in the G0/G1 cluster. Most cells reside in a cluster left from the $\mathrm{G} 0 / \mathrm{G} 1$ cluster (labeled $\mathrm{Gl}^{\prime}$ ). These cells underwent one round of BrdU incorporation during $S$ phase and halved their DNA content after traverse of the $\mathrm{G} 2$ compartment of the cell cycle. The trail moving to the right side and up from the $\mathrm{G} 1^{\prime}$ cluster represents cells passing through a second $\mathrm{S}$ phase (labeled $S^{\prime}$ ) and a second G2 phase (G2'). Due to the bifiliary BrdU substitution, this trail no longer moves to the left, but still some additional quenching of Hoechst fluorescence is afforded during the second cycle $S$ phase. Cells that underwent a second mitosis during $72 \mathrm{~h}$ of culture appear to the left of the G1' cluster in a cluster labeled G1". Also, a few signals representing cells in the $S$ phase of the third cycle can be seen. The panel representing a culture exposed to Il-4 shows a less elaborate picture: most cells are retained in the G0/G1 cluster and a few reached the second and third cycle $\mathrm{G} 1$ phase $\left(\mathrm{G} 1^{\prime}\right.$ and $\mathrm{G} 1^{\prime \prime}$, respectively). The combination of Il-2 and Il-4 lead to a cytogram roughly similar to that of the Il- 2 exposed culture.

Quantification of the data obtained of the cultures stimulated with Il-2, Il-4, or both for 24,48 , or $72 \mathrm{~h}$ is shown in Table 1. These data are corrected for the number of cell divisions a given cell has undergone and exclude the population of dead cells or dying cells. Table 1 shows calculations for the first, second, and third CC.

Without the addition of either II- 2 or Il-4, all the 
Figure 2. Bivariate Hoechst/ ethidium bromide cytogram of PHA-activated cell cultures continuously labeled with $100 \mu \mathrm{M}$ BrdU in the presence of the indicated interleukins.

The abscissa displays BrdU. quenched Hoechst fluores. cence, whereas the ordinate shows unquenched ethidium bromide fluorescence. The first cycle compartments are labeled $\mathrm{GO} / \mathrm{G} 1, \mathrm{~S}, \mathrm{G} 2$; the second cycle compartments $\mathrm{G}^{\prime}, \mathrm{S}^{\prime}, \mathrm{G} 2^{\prime}$, and the third cycle compartments Gl" and $\mathrm{S}^{\prime \prime}$.

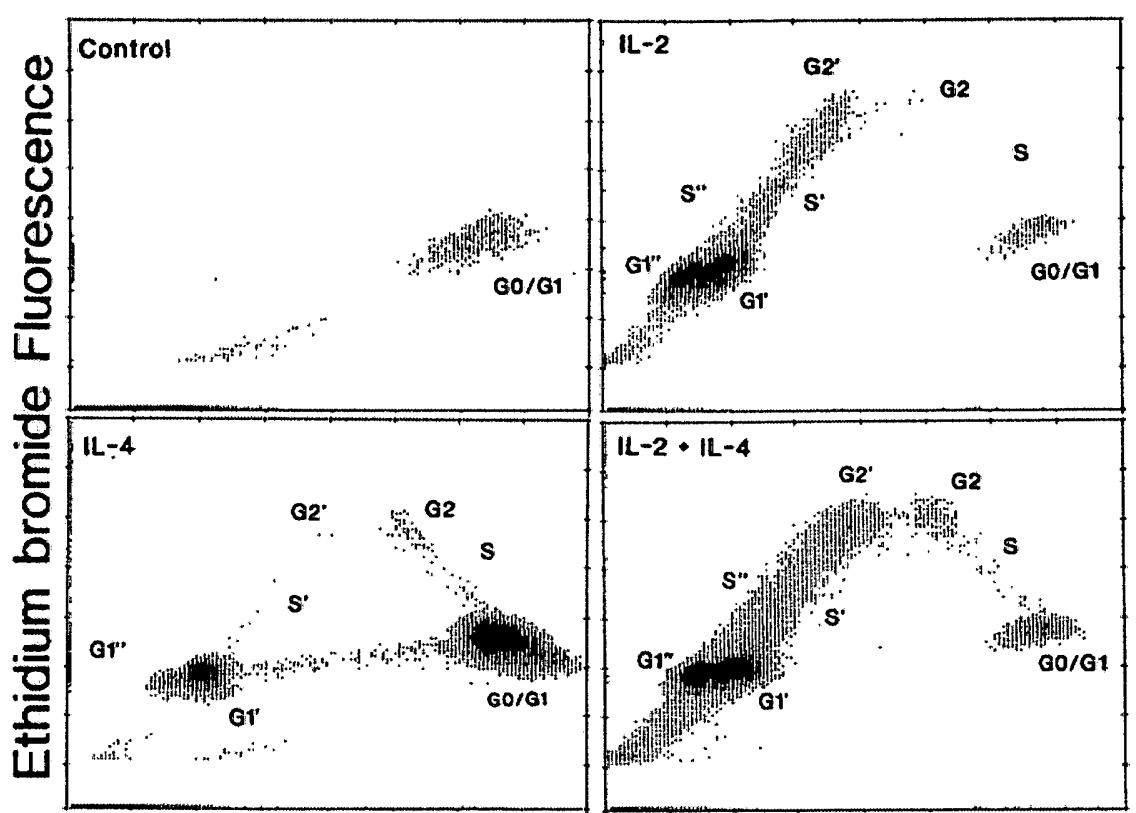

BrdU/Hoechst Fluorescence
PHA-activated T cells rest in the G0/G1 phase of the first CC. After 24 h with Il-2, Il-4, or both, about $99 \%$ of the cells remain in the first cell cycle. With either Il-2 or the combination of Il- 2 and Il-4, approximately $20 \%$ of the cells enter the $\mathrm{S}$ phase of the first $\mathrm{CC}$, whereas this was seen only by $9.2 \%$ of cells stimulated with II-4 alone. None of the cells leave G1' (G1 phase of the second $\mathrm{CC}$ ) when exposed for $24 \mathrm{~h}$ to the lymphokines.

After $48 \mathrm{~h}$ with $\mathrm{Il}-4$ alone, $89.9 \%$ of the cells remain in the $\mathrm{G} 0 / \mathrm{G} 1$ phase of the first $\mathrm{CC}$ whereas $3.3 \%$ of the cells leave the first $\mathrm{CC}$ but are arrested in G1'. With Il-2 or the combination of both lymphokines, approximately $25 \%$ of the cells remain in $\mathrm{G} 0 / \mathrm{G} 1$ of the first CC, approximately $40 \%$ of the cells are in the second $\mathrm{CC}$, and $<2 \%$ are already in the third CC. Of the $40 \%$ of cells in the second CC, about half enter the $S$ phase.

When exposed for $72 \mathrm{~h}$ to Il-4, the majority of cells still remain in G0/G1 of the first CC. Approximately $12.7 \%$ of the cells leave the first $\mathrm{CC}$ to enter the second and only $1.2 \%$ leave the second $\mathrm{CC}$ to enter the third $\mathrm{CC}$, but there are no cells in the $\mathrm{S}$ phase of the third CC. Thus, a total of $21.6 \%$ of cells stimulated with Il-4 alone undergo one or two divisions in the first $72 \mathrm{~h}$ after addition of the lymphokine. In contrast, stimulated with Il-2 or with the combination of Il-2 and Il-4,

TABLE 1. Cell cycle distribution of PHA-activated $\mathrm{T}$ cells stimulated with the indicated interleukins.

\begin{tabular}{|c|c|c|c|c|c|c|c|c|c|}
\hline & \multicolumn{3}{|c|}{ First CC } & \multicolumn{3}{|c|}{ Second CC } & \multicolumn{3}{|c|}{ Third CC } \\
\hline & $\mathrm{G} 0 / \mathrm{G} 1$ & $\mathrm{~S}$ & G2 & $\mathrm{G} 0 / \mathrm{Gl}$ & $S$ & G2 & $\mathrm{G} 0 / \mathrm{G} 1$ & $\mathbf{S}$ & $\mathrm{G} 2$ \\
\hline \multicolumn{10}{|l|}{$24 \mathrm{~h}$} \\
\hline Control & 100 & 0 & 0 & 0 & 0 & 0 & 0 & 0 & 0 \\
\hline Il-2 & 73.3 & 22.4 & 2.7 & 1.6 & 0 & 0 & 0 & 0 & 0 \\
\hline Il-4 & 90.2 & 9.2 & 0 & 0.6 & 0 & 0 & 0 & 0 & 0 \\
\hline [l]-2/I]-4 & 78.6 & 19.2 & 0.7 & 1.5 & 0 & 0 & 0 & 0 & 0 \\
\hline \multicolumn{10}{|l|}{$48 \mathrm{~h}$} \\
\hline Control & 100 & 0 & 0 & 0 & 0 & 0 & 0 & 0 & 0 \\
\hline Il-2 & 24.3 & 22.5 & 8.7 & 24.8 & 14.7 & 2.7 & 2.3 & 0 & 0 \\
\hline I]-4 & 89.9 & 6.7 & 0.1 & 3.3 & 0 & 0 & 0 & 0 & 0 \\
\hline Il-2/Il-4 & 27.1 & 27.6 & 6.8 & 23.2 & 12.2 & 1.8 & 1.3 & 0 & 0 \\
\hline \multicolumn{10}{|l|}{$72 \mathrm{~h}$} \\
\hline Control & 100 & 0 & 0 & 0 & 0 & 0 & 0 & 0 & 0 \\
\hline Il-2 & 13.2 & 5.9 & 5.9 & 26.4 & 23.8 & 4 & 17.1 & 3.6 & 0.1 \\
\hline []-4 & 78.4 & 7.5 & 0.2 & 10.1 & 2.2 & 0.4 & 1.2 & 0 & 0 \\
\hline I] $-2 /$ Il- 4 & 14.6 & 7.2 & 7.5 & 30.2 & 16.4 & 6.6 & 12.9 & 4.4 & 0.2 \\
\hline
\end{tabular}


over $70 \%$ of cells are capable of entering the second or third CC (three times more cells than stimulated with Il-4 alone). Approximately $14 \%$ of cells are still in $\mathrm{G} 0 / \mathrm{G} 1$ of the first $\mathrm{CC}$, whereas $54.2 \%$ and $53.2 \%$, respectively, enter the second $\mathrm{CC}$ and $20.8 \%$ and $17.5 \%$, respectively, enter the third CC. With Il-2 or the combination of both Il-2 and Il-4, approximately $4 \%$ of the cells undergo three divisions, whereas with Il-4 alone none of the cells could divide more than twice.

\section{DISCUSSION}

The stimulatory effect of the lymphokines Il-2 and Il-4 on activation and proliferation of T cells can be examined with unprecedented precision by the bivariate $\mathrm{BrdU} / \mathrm{Hoechst}$ technique. The number of noncycling cells can be analyzed at various time points after activation, and among the cycling cell fraction, one can distinguish at least three sequential rounds of DNA synthesis. Moreover, the distribution of cells throughout individual CC compartments and accumulation of cells in single compartments can be ascertained.

T-cell proliferation is mostly investigated by $\left[{ }^{3} \mathrm{H}\right]$ thymidine incorporation. Our preliminary data show that detection of proliferating cells by incorporation of $\left[{ }^{3} \mathrm{H}\right]$ thymidine and by incorporation of the thymidine analogue $\mathrm{BrdU}$ gives comparable results. Limited data concerning cell kinetics of $T$ cells stimulated with Il-2, Il-4, or the combination of both lymphokines are now available. Thus, with the bivariate BrdU/Hoechst analysis, new aspects concerning the Il-2 or Il-4 effects on CC progression of T cells are revealed. Il-2 and Il-4 as well can drive the PHAactivated $\mathrm{T}$ cells through one and more CCs and not only to the $S$ or $\mathrm{G} 2$ phase of the first CC. When exposed $72 \mathrm{~h}$ to Il-4, nearly $80 \%$ cells are secluded in G0/G1 of the first CC, but more than $10 \%$ of the cells are found in the second and more than $1 \%$ are found in the third CC. In contrast, after $7.2 \mathrm{~h}$ with either Il-2 alone or Il- 2 and Il- 4 combined, only about $25 \%$ of the cells remain in the first $\mathrm{CC}$, whereas approximately $55 \%$ of the cells have entered the second and $20 \%$ of the cells have entered the third CC. In our test system, because Il- 2 is shown to drive many more cells through the CCs than Il-4 and because there was no additive effect of the two lymphokines, one is tempted to conclude that the population Il-4 responsive cells is at least an overlapping, if not a real subset of the population of the $\mathrm{Il}-2$ responsive cells; this means that in our test system, all or most Il-4 responders are also Il-2 responders, whereas only some Il-2 responders are also Il-4 responders. This finding would be compatible with recent reports showing that, in the mouse system, Il-4.can act as an analogue of Il-2 on some or all T cells ${ }^{13}$ and that most human T-cell clones selected in Il- 2 are also able to respond to Il- $4 .^{10}$

In this study, the simultaneous stimulation of PHA-activated T cells with both Il-2 and Il-4 shows neither an inhibitory nor a synergistic effect in comparison to Il-2 alone. Furthermore, the combination of both lymphokines exerts a stronger effect on proliferation of $\mathrm{T}$ cells than $\mathrm{Il}-4$ alone. $\mathrm{Il}-2$ is a more potent stimulating factor on $\mathrm{T}$ cells than Il-4. These results obtained in the $\left[{ }^{3} \mathrm{H}\right]$ thymidine assay are confirmed in the CC compartment analysis where there was a similar pattern of the distribution of $\mathrm{T}$ cells in the different $\mathrm{CC}$ compartments for the stimulation with either Il-2 alone or the combination of both Il-2 and Il-4.

Recently, discordant findings of lymphokinedependent proliferation of $\mathrm{T}$ cells were reported. Habetswallner et al. ${ }^{14}$ reported that simultaneous addition of Il-2 and Il-4 did not result in an additive or synergistic effect on T-cell proliferation to either lymphokine alone. In contrast, Mitchell et al. ${ }^{9}$ described that Il-2 and Il-4 combined support a greater degree of proliferation than Il-2 or Il- 4 alone. Martinez et al. ${ }^{11}$ observed that Il-4 enhanced the proliferation of T cells already activated by anti-CD3 $\mathrm{mAb}$ and Il-2. On the other hand, when $\mathrm{T}$ cells were cultured with anti-CD3 $\mathrm{mAb}, \mathrm{Il}-2$, and Il-4 simultaneously, the proliferation response was diminished as compared with that of anti-CD3 mAb and Il-2 alone. " The addition of Il-4 also inhibits Il-2-induced proliferation in all lymphocyte population. ${ }^{15}$

All these data suggest that the proliferation of $T$ cells is critically dependent on the test system which includes the nature and intensity of the stimulus, the preactivation of the cells, and the time point and the period of the addition of the different lymphokines. It is presently unclear which subpopulations of $\mathrm{T}$ cells are Il-2 responders and which are Il-4 responders. For further investigations on the lymphokine-induced T-cell proliferation, BrdU/Hoechst flow cytometry may provide a very informative tool.

\section{MATERIALS AND METHODS}

\section{Interleukins}

The II-2 and Il-4 preparations were Escherichia coliproduced Il-2 and Il-4. The biological activity of Il-2 was determined by using $\left[{ }^{3} \mathrm{H}\right]$ thymidine incorporation into an Il-2-dependent murine T-cell line (CTLL-2; ATCC MB214). ${ }^{16}$ $T$ cells activated with PHA for 7 days and then incubated with Il-4 for $72 \mathrm{~h}$, were used to determine the biological activity of Il-4 using [ $\left.{ }^{3} \mathrm{H}\right]$ thymidine incorporation (modified accordingly $\left.{ }^{8}\right)$. One unit is the amount of rIl-2 or rIl-4 that provides a signal $50 \%$ of that elicited by saturating amounts of lymphokine. 


\section{Preparation of PHA Activated T Cells}

Peripheral blood mononuclear cells (PBMC) from normal individuals were separated by Ficoll-Hypaque density gradient centrifugation. PBMC were cultured in RPMI 1640 medium (Gibco, Grand Island, NY) with $10 \%$ fetal calf serum (FCS, Gibco) $\left(1 \times 10^{7}\right.$ cells $\left./ \mathrm{mL}\right)$ in the presence of 2 $\mu \mathrm{g} / \mathrm{mL}$ phytohemagglutinin HA-15 (Wellcome, Research Triangle Park, $\mathrm{NC}$ ) in a humid athmosphere with $5 \% \mathrm{CO}_{2}$ at $37^{\circ} \mathrm{C}$ for 7 days.

\section{$\left[{ }^{3} \mathrm{H}\right]$ Thymidine Incorporation Assay}

The PHA-activated $\mathrm{T}$ cells were extensively washed then $1 \times 10^{5}$ cells were placed in a 96-well flat-bottom plate and cultured in $200 \mu \mathrm{L}$ of RPMI 1640 containing $10 \%$ FCS in the presence of the recombinant lymphokines II-2, Il-4, or of both for 24,48 , or $72 \mathrm{~h}$. The culture was then pulsed with 0.5 $\mu \mathrm{Ci}\left[{ }^{3} \mathrm{H}\right]$ thymidine (Amersham Corp., Arlington Heights, IL) for the last $6 \mathrm{~h}$ and then harvested onto glassfiber filters (Scatron, Oslo, Norway). The radioactivity was counted by liquid scintillation. All data are indicated as the mean counts per minute of at least triplicate cultures.

\section{Bromodeoxyuridine Labeling}

PHA-activated T cells were exposed to the interleukins as described above, and concomitantly the culture medium was supplemented with $100 \mu \mathrm{M}$ of BrdU and deoxycytidine. All culture plates were carefully wrapped in aluminum foil to avoid exposure to light of short wavelengths. After 24,48 , or $72 \mathrm{~h}$ of culture, cells were harvested under illumination with red light only. Until analysis, cells were stored in the dark at $-20^{\circ} \mathrm{C}$ in culture medium supplement with $10 \%$ FCS and $10 \%$ dimethylsulfoxide.

\section{Cell Staining and Flow Cytometry}

After thawing, cell pellets were resuspended in a staining buffer containing $1.2 \mu \mathrm{g}$ of Hoechst 33258 and $2.0 \mu \mathrm{g}$ of ethidium bromide per milliliter of buffer ${ }^{17,18}$ Flow cytometric analysis was performed with an epillumination system of conventional design (ICP 22, Ortho Diagnostic Systems, Raritan, NJ) equipped with a mercury arc lamp (HBO 100, Osram, Berlin, Germany). Bivariate cytograms of Hoechst and ethidium bromide fluorescence were digitalized and recorded with a PDP 11/23 microcomputer (Digital Equipment Corporation, Maynard, MA). Cells belonging to three successive CCs can be distinguished due to BrdU quenching of Hoechst fluorescence. ${ }^{1719}$ By electronic selection of the signal clusters representing each $\mathrm{CC}$, rotation, and deconvolution, conventional $\mathrm{CC}$ distributions were obtained, which were fitted with a standard CC algorithm (Phoenix Flow System, San Diego, CA). The cell numbers in each $\mathrm{CC}$ were normalized to the percentage of original cells by correcting for the numbers of cell divisions by which cells originated.

\section{Acknowledgment}

The authors thank C. Harmening for skilful technical assistance.

This work was supported by Deutsche Forschungsgemeinschaft Grant Ho 849/2-2.

\section{REFERENCES}

1. Howard M, Farrar J, Hifliker M, Johnson B, Takatsu K, Hamaoka K, Paul WE (1982) Identification of a T-cell derived B cell growth factor distinct from interleukin-2. J Exp Med 155:914-923.

2. Paul WE, Ohara J (1987) B-cell stimulatory factor-1/ interleukin 4. Ann Rev Immunol 5:429-459.

3. Nagler A, Lanier LL, Phillips JH (1988) The effects of Il-4 on human natural killer cells. A potent regulator of Il-2 activation and proliferation. J Immunol 141:2349-2351.

4. Spits H, Yssel H, Paliard X, Kastelein R, Figdor C, deVries $\mathrm{JE}$ (1988) Il-4 inhibits Il-2-mediated induction of human lymphokineactivated killer cells, but not the generation of antigen-specific cytotoxic T-lymphocytes in mixed leukocyte cultures. J Immunol 141:29-36

5. Jelinek DF, Lipski PE (1988) Inhibitory influence of Il-4 on human B cell responsiveness. J Immunol 141:164-173.

6. Tigges MA, Casey LS, Koshland ME (1989) Mechanism of interleukin 2 signaling. Mediation of different outcomes by a single receptor and transduction pathway. Science 243:781-786.

7. Rabin EM, Mond JJ, Ohara J, Paul WE (1986) Interferongamma inhibits the action of B-cells stimulatory factor (BSF)-1 on resting B-cells. J Immunol 137:1573-1576.

8. Yokota T, Otsuka T, Mosmann T, Banchereau J, DeFrance T, Blanchard D, deVries JE, Lee F, Arai KI (1986) Isolation and characterization of a human interleukin cDNA clone, homologous to mouse B-cell stimulatory factor 1, that expresses B-cell- and T-cellstimulating activities. Proc Natl Acad Sci USA 83:5894-5898.

9. Mitchell LC, Davis LS, Lipsky PE (1989) Promotion of human T-lymphocyte proliferation by Il-4. J Immunol 142:1548-1557.

10. Uchiyama T, Kamio M, Kodaka T, Tamori S, Fukuhara S, Amakawa R, Uchino H, Araki K (1988) Leukemic cells from some adult T-cell leukemia patients proliferate in response to Interleukin-4. Blood 72:1182-1186.

11. Martinez OM, Gibbons RS, Garovoy MR, Aronson FR (1990) Il-4 inhibits Il-2 receptor expression and Il-2-dependent proliferation of human T cells. J Immunol 144:2211-2215.

12. Spits H, Yssel H, Takebe Y, Arai N, Yokota T, Lee F, Arai Kl, Banchereau J, deVries JE (1987) Recombinant Interleukin 4 promotes the growth of human T-cells. J Immunol 139:1142-1147.

13. Brown M, Hu-Li J, Paul WE (1988) Il-4/B-cell stimulatory factor 1 stimulates T-cell growth by an Il-2 independent mechanism. J Immunol 131:504-511.

14. Habetswallner $H$, Pelosi $E$ Bulgarini $D$, Camagna $A$, Sammoggia P, Montesoro E, Gianella G, Lazzaro D, Isacchi G, Testa U, Peschle C (1988) Activation and proliferation of normal resting human T lymphocytes in serum-free culture: Role of Il-4 and Il-6. Immunology 65:357-364.

15. Han X, Itoh K, Balch CM, Pellis NR (1988) Recombinant Interleukin 4 (rIl4) inhibits Interleukin 2-induced activation of peripheral blood lymphocytes. Lymphokine Res 7:227-235.

16. Gillis S, Ferm MM, Ou W, Smith KA (1978) T cell growth factor: Parameters of production and a quantitative micro assay for activity. J Immunol 120:2027-2032.

17. Rabinovitch PS, Kubbies M, Chen YC, Schindler D, Hoehn H (1988) BrdU-Hoechst flow cytometry: A unique tool for quantitative cell cycle analysis. Exp Cell Res 174:309-318.

18. Poot M, Schmitt H, Seyschab H, Koehler J, Chen U, Kaempf U, Kubbies M, Schindler D, Rabinovitch PS, Hoehn H (1989) Continuous bromodeoxyuridine labeling and bivariate ethidium bromide/Hoechst flow cytometry in cell kinetics. Cytometry 10:222-226.

19. Rabinovitch PS (1983) Regulation of human fibroblast growth rate by noncycling cell fraction and transition probability is shown by growth in 5-bromodeoxyuridine followed by Hoechst 33258 flow cytometry. Proc Natl Acad Sci USA 80:2951-2955. 